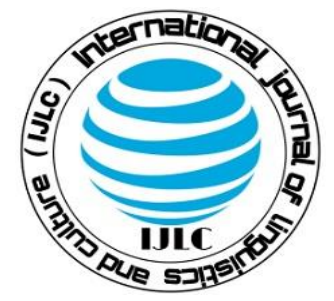
Volume \& Issues Obtainable at The Women University Multan
International Journal of Linguistics and Culture
ISSN (Print): 2707-6873, ISSN (Online): 2788-8347
Volume 2, No.1, June 2021
Journal homepage: http://ijlc.wum.edu.pk/index.php/ojs

\title{
Fragmentation and Postmodern studies: An analysis of Mohsin Hamid's Novel "How to get filthy rich in rising Asia".
}

\author{
Uzma Munir \\ Department of English, National University of Modern Languages, \\ Islamabad (Multan Campus), Pakistan. \\ Email: uzma@numl.edu.pk \\ Qamar Sumaira \\ Department of English, \\ Institute of Southern Punjab, Multan, Pakistan. \\ Email: qsumaira@hotmail.com
}

\begin{abstract}
In this study, the fragmentation as postmodernist narrative technique in Mohsin Hamid's novel "How to get filthy rich in rising Asia" is examined. He uses structural inequalities, grammatically incorrect sentences, phrases and dependent clauses. The term fragmentation is coined by Bell Hooks to highlight the problem of "hierarchy of oppression" within the feminist paradigm. Fragmentation is the major thematic concern of postmodern art that sets new parameters for the narrative techniques of postmodern literature. Fragmentation in the literary work involves complexity on semantic level where the various words act as signifier and signified at the same time. Therefore, this study probes the fundamentals of fragmentation in the text that reflects the radical changes in the postmodern society and focuses on the little narratives that create fragmented truth and cause anarchy, uncertainty and chaos in the world.
\end{abstract}

Keywords: Postmodernism. Modernism. Fragmentation. Linguistic Fragmentation. Fragmented Ideology. Cultural Hybridity. Nuclear Family System.

\section{Introduction.}

Ronal and Henryk (Jones, 2000) defines Fragmentation as "breaking up initially collective production process into two or more components". In general, fragmentation means the state of splitting whole process into various components. Postmodernists see the world as contingent, 
ungrounded, fragmented, unstable and a set of disunities cultures or interpretations that bring forth skepticism about the objectivity and reliability of truth, history and norms, the elements of nature and coherence of identities (Davis, 2003) Postmodernism is a style of culture that reflects something of this epochal change, in a depthless, de-centered, ungrounded, self-reflexive, playful, derivative eclectic, pluralistic art and blurs the boundaries between high and popular culture as well as between art and everyday experience (Davis, 2003).

Focault's critique about modernity is first step in the direction of anti-enlightenment rituals that discard the balance of reason, enfranchisement and progress. He argues that contemporary forms of supremacy and awareness have created powerful manifestation of domination over human beings. Focault is follower of Nietzsche position that reject the enlightenment ideology of historical progress (Best \& Kellner, 1991). The crucial elements of modernism were the dominancy of power and scientific technology over wisdom, in-dependency and identity, to impart urban habits, and the ways of life that cause to occur the collapse of social and cultural hierarchies. On the contrary, the influential feature of postmodernism is to put disbelief in practice which could be ascertain to have a look at the crucial crisis in the Victorian period when power of Christianity was decreased due to evolution and scientific discoveries (Gregson, 2004). It is emphasized in Francois Lyotard's 'The postmodern condition: A Report on knowledge' (Lyotard, Bennington, \& Massumi, 1984), that influential impact of technology in media is television, which is related with the postmodern phenomenon. Television provides multiple options for viewers to jump over different eras by pressing one button of remote control. Social media manipulate one news through different channels. Every channel promotes explicitly different ideology among viewers that call forth faulty perception of reality (fragmented ideology). The postmodernism is prominent movement that appears in multiple dimensions. It includes art, architecture, music, film, literature, sociology, communications, fashion industry and technology. Postmodern work is not bounded by any specific genre. Postmodernists deny the rational and logical way of thinking and put more focus on the totalizing discourses which arise the questions about hegemonic discourses.

Subsequent to the civil right movement in USA, in 1960, the American literature overtly depicted the multiple worse aftereffects of industrialization, capitalism and consumerism. In difference to the commercialization of brand names by celebrities, postmodernists put stress upon radical plurality where truth is represented as mere reflection of creativity, which is unstable, unfixed and unfinished 
and can be transformed and changed. Jameson distinguished between the modern and postmodern music and argued that, Beatles and rolling stones represent the music of modern era while punk rock and new wave is considered as postmodern music and was appreciated due to the freedom and natural feelings without constraint that brought change in the form of art and literature. Pop jazz, rock bands and music such as rolling stone was used to repeat aloud on public places and became famous due to its unique formation in style, openness, irregular and unusual rhythm and fragmented pattern of music and lyrics (Sim, 2011).

Many marginalized authors such as gay, lesbians, females became postmodern authors for their postmodern narrative techniques and they had to strive a lot to gain basic social rights to enroll themselves as equal entity in the society. Postmodern literary text does not follow the original and authentic rules of fiction and re-contextualize the old literary form with modified knowledge of language and heartening contexts to articulate clear discrepancy between ancient times and present. While analyzing the literary text of this era, a postmodernist does not only write openly about outcast characters rather other deviants such as homosexual and prostitutes are also being focused (Sim, 2011). Similarly, (Al-Nakeeb, 2018) has closely examined the anatomical elements of males and females in a Yemeni Novel "Final Flight from Sanna", where he highlighted of power relation and cultural difference between men and women of east and west society. He is of the view that inspite of equal fragmentation in both gender's bodies they are portrayed differently.

Postmodern literature is the true reflection of postmodern life and culture which eliminates the discriminatory elements of identity such as sexual, cultural and ethnicity. After civil right movements in USA, many efforts were made to bring the existence of marginalized people in the Centre. Postmodernism is the result of emergence of feminism and post-colonialism as females, gays, lesbians and black people got prominent position in the society after the revolutionary protest to legitimize the existence of de-centralized group of people to get equivalent opportunities in different spheres of life. The world is closely affected by the advancement in technology and communication through media such as by using mobile phones, computers, internet, and film that spread pop culture all over the world.

Postmodernism is an extension of modernism that keeps alive the original dimensions of any subject matter and challenge the assumptions prevailed by the modernists in the society. According to 
Lyotard et. al. , the concept of grand narratives is known as emancipation narrative (Lyotard et al., 1984), that depicts the interconnection between events related to each other and describes a social continuous hierarchy and gradual development that cause to execute the sense of history collectively rather than focusing on particular isolated events in history. Moreover, he is of the view that in postmodern era, people are more interested in little narratives and grand narratives are considered oppressive. For, every grand narrative excludes.

Michael explained linguistic fragmentation as various languages and dialects used by large portion of a nation's population (Duffy, 1989).

The postmodernism is more related to deconstruction as it is based on the Foucault's notion that human science should be treated as autonomous system of discourse. Deconstruction is a philosophical literary criticism and textual analysis developed by Derrida (Derrida, 1971). He is of the view that theory of language is much more slippery and ambiguous than we realize. Three concepts of deconstruction are more related with postmodernism and fragmentation.

1. Language is vibrant, ambiguous, unstable and continually propagate possible meanings.

2. Existence has no Centre, no stable meaning, and no fixed ground.

3. Human beings have fragmented ideologies so their "identities" are the one we invent and chose to believe.

4. Truth is just reflection of one perspective which can never be finished, stable or eternal, but it is always opened and can be changed, transformed, modified or even destabilized by different versions of reality by mixing of fragmented genres, such as, pornography, love story and suspense that enhances its stylistic hybridity.

Stevi Jackson and Jackie jones wrote in the book 'Contemporary Feminist Theories' that the phenomenon of Post of Postmodernism is emerged in 1970s with other terms such as, Post-Industrialism, Post-Marxism, Post-Humanism, and Post Feminism.(Jackson \& Jones, 1998) Postmodernists are of the view that science, ethics and art should not be considered as separate knowledge. Thus, postmodernists reject the idea of an objective science and law to uncover different versions of existing reality. Post feminism contributed a lot as critique of enlightenment, whereas recently a number of postmodern symptoms are seen in feministic theory (Jackson \& Jones, 1998). Susan Sontag calls postmodernism as new sensibility that can erase the 
distinction between Low(lower middle class) and High(Elite class) that put aside the cultural elitism of Modernism (Sontag, 1966).

\subsection{Main research problem.}

"How to get filthy rich in rising Asia" seems to be a postmodern novel as it has multiple characteristics of postmodern literary work like meta-fiction, irony, playfulness, fragmentation, chaos, uncertainty and anarchy (Hamid, 2013). The identities of various characters are fragmented and the plot is also not linear. The complexity at the level of lexis, plot, characters and symbols adds up to its postmodern nature. Symbolism and imageries used in novel challenges the ideologies settled in the reader's mind which is a true evidence of postmodern work.

\subsection{Research questions.}

- Does the overlapping or multiple narrative represent fragmented truth of society?

- Does the linguistic hybridity enhance the interest of the reader?

- What are the elements that make a fiction as meta fiction?

\subsection{Objective of the study.}

This study addresses the fragmented elements in the literary composition and structure of the narrative. We will investigate the fragmentation in plot construction, characters, theme and diction.

\section{Literature review.}

In $18^{\text {th }}$ century, there was order, law, rationality, technology and unity in the society. It is quite true that the ideology of modernists and postmodernists have much common. Uncertainty, alienation and fragmentation are common characteristics of modern and postmodern art. Modernists used to consider fragmentation as sense of sadness that should be mourned. Many modernists tried to bring order in the society through art where the meaning was totally lost. However, postmodernists do not yearn for these qualities rather they promote fragmentation to 
create playful texts that manifest and look into the confusion and complexities of the world. The significant element of postmodernism is disintegration of social norms, behavior, and thoughts.

John Hill inscribed the fragmentation in postmodern paradigm,(Hill \& Pamela, 1998) he explains that postmodernism cannot be understood by the fragmented styles of thinking rather it is considered separately for its discrete nature.

Nobert Willey conveyed the concept of self as fragmented, fluid, defenseless that lacks identity (Wiley, 2012), and it was considered as most contemporary ideology. He divides the self in three significant levels; the most superficial level is Quotidian level which belongs to the everyday habits, minor practices and idiosyncrasies of individuals, the second level is Identity level i. e communal identities, individual identities and self-perception, and the third level is Generic level. During $18^{\text {th }}$ and $19^{\text {th }}$ century, many modern European novels have influenced the Asian writers to pay attention towards industrialization. English, French, Dutch languages and cultures were forcefully imposed upon the colonies which promoted the western literature, ideas of common-wealth literature more rapidly (Littrup, 1996).

John Hawker says that many authors worked to forget the four cornerstones (plot, character, setting, theme) in the fiction. Subsequently, plot is fragmented into different scenarios that make it nonlinear, characters are disintegrated with seemingly abrupt uncontrolled motions, setting are transitory, background and themes are inconsistent and unusual. The postmodernists condemn the grand narratives in the traditional stories and deal with fragmented way of structuring narrative that can enlighten the little narratives in the text. Postmodernists tend to believe that every ending offer numerous possible outcomes for interpretation of story. John Fowles in his postmodern novel "The French Lieutenant's woman" discussed the complex relationship of Charles Smithson and amateur naturalist Sarah woodruff (Fowles, 1969). It follows pattern of traditional love story, however, narrative is deviated from the conventional historical romance. He also made a break in the narrative by directly pointing the reader and steps into the story as character. This novel is an open horizon for reader to explore the multiple meaning by separating text into short fragments or segments, disintegrated by symbols, images, numbers, titles or spaces. Raymond Federman in his novel put material (pieces of other discourses, charts, designs, 
diagrams and pictures) into the spaces where there is nothing required to write and is irrelevant to the story as well (Federman, 1975).

A postmodern novel "Willie Master's Lonesome wife (1967)" is an excellent example of fragmentation, where the Sixty odd pages are in four different colors: jotter blue, strawberry red, khaki green and glossy white (Gass, 1998). An unusual front page is designed with lounging nude woman. Fragmentation in the text can be seen by use of multiple typefaces (bold, italics), fonts (gothic, script), characters (musical symbols, accents) and haphazard arrangement of columns and footnotes, and some visual jokes (coffee-cup, stains, huge asterisk).

Angela McRobbie addresses two problems with postmodernism in "Postmodernism and Popular Culture"; the very first problem is related with the term "fragmentation", this term is being overused in contemporary cultural debates that draws multiple meanings (McRobbie, 1994). According to Fredric Jameson the weakness of popular culture is reflective in the schizophrenic individuals of collective consciousness (Jameson, 1991). On contrary, Stuart Hall argued that fragmentation is decentering of consciousness which allows him as black person to emerge and divide and that is first stage of postmodernity (Hall, 1993). He states that marginalized people of society (e.g. black people) are now Centre of society due to fragmented subjectivity. Jean Francois Lyotard calls "postmodernity" as an age of fragmentation and pluralism (Lyotard et al., 1984).

Angela raised few questions about the fragmentation of self: have "we" become more fragmented than before? Can we specifically name a time and a place for the moment of fragmentation? Is fragmentation the 'other' of 'humanity'? Or is the representation of fragmentation coincidental with political empowerment and liberation? (McRobbie, 1994) Christopher Norris argued about postmodernity through research that initiates with Saussure, carried through postmodernism and Lacanian psychoanalysis and ends with Baudrillard (Norris, 1990)

Now a days fragmented subjectivity is more expressed in the modern cultures with amalgamation of multiple styles. The major concern about fragmented subjectivity is that who is able to express language of their broken subjectivities through words, images and sounds and who is inclined to listen such stories. Fragmentation can be connected with the politics of 
empowerment and a chance to mount challenge. However, for James and other white middle class masculinity, fragmented subjectivity is more related with disempowerment, quietness, schizophrenic cries and whispers (McRobbie, 1994). In the literature (NARGES, 2018), authors have proposed that due to linguistic fragmentation, many technical and psychological changes are revealed in current literature of Iran or America. According to Moulai and Bessafi (MOULAI, 2018) "fragmentation" is used as narrative technique in the novel "To The Lighthouse" (Woolf, 1981) with nonlinear structure of plot to represent train of thoughts. Cataphoric and anaphoric references are used to develop the content. The novel leaves greater room for the reader to piece together different parts of plot for understanding.

Bendikson has concluded in "Postmodernist Fragmentation and Non-linearity: An Experience of Time with the Capitalist Framework" through the analysis of novels: American Psycho, Fight Club and Cosmopolis, that due to all dramatic changes occurred after the emergence of late capitalism, we are able to understand postmodern narrative techniques: nonlinearity and fragmentation. These terms are related with ambivalence and highlights how an organic process and understanding of time is distorted (Bendiksen, 2017). 


\section{Research methodology}

\subsection{Nature of the study.}

Fragmented narratives confuse the sequencing of story that seeks reader's attention to piece together different components of story. Fragmented narratives usually moves back and forth throughout the lifetime events in the story. It sometimes creates chaos for the reader to understand the whole scenario. Fragmentation can be seen at certain levels such as temporal distortion and spatial distortion. It seems while reading the novel "How to get filthy rich in rising Asia"; things are happening with the blink of eye, as the years are passed and the little rural boy grown up and reach the middle age and finally reached to the last phase of his life.

Hamid (Hamid, 2013) depicts several settings e.g., where pretty girl and rural boy meet each other, the setting of village and big city, the setting of government school, organizations and offices. He uses temporal and spatial distortion technique (linguistic fragmentation) to narrate a story. He also uses significantly complex wording to create confusion and chaos. The plot proceeds with ambiguous ideologies and unnamed characters with cataphoric and anaphoric reference to make the text playful. Hamid uses second person narration "you" that transforms reader into character that drag them inside the story. It seems as it is hand book of everyone.

\section{Critical analysis}

"How to Get Filthy Rich in Rising Asia" is a fragmentary novel. It consists of 12 chapters that are part of whole book. These fragments in text delight readers with remarkable turn of events. All the elements of craftsmanship i.e., plot, dialogues, characters, settings, theme represent fragmentations of society through behavior, class system, ideologies, social evils, opportunities and relationships. 


\subsection{Fragmentation in society}

Hamid states the terrible anguish of rural boy's mother when she is skeptic that her son is going to die or not. An example of fragmented society is the diverse emotional thought process of its inhabitants. There are multiple layers of dissatisfaction and chaos in her mind that motivate reader to explore in-depth layers of shaded reality.

The two main characters "rural boy" and "pretty girl" are disorganized, independent and emotional inhabitants of unnamed big city of Asia. Both spent more than half of their lives separate and experienced different phases of life (youth and money, glamour and power, old age and betrayal). Initially pretty girl is more skeptic about the rapid progress of rural boy when she shows wonder that how he became business man from being a worker in DVD shop. A wide difference of "low (lower middle class)" and "high (elite class)" in society mirrors fragmentation and bring less harmony in relationships.

Fragmentation in society inculcates poor relationships and economical inequalities due to corruption and class system that bring anarchy in the society. Hamid ironically refers that all the ways from rags to richness are through munching on others assets. He points out the prevailed corruption in the developing Asia.

Nuclear family system represents west culture and apparently is not that bad but in many societies married couple do not share their responsibilities equally and nuclear families are fragmented into single parent families or no families. The rural boy in his early childhood was lived in joint family system that turned into nuclear family system when he moved to city and he further separated himself and after marriage again remained in nuclear system but felt himself misfit there and both started living separate. The decision of rural boy to get married based on material benefit. The rural boy's wife is half of his age but after marriage, he still aspires for the love of pretty girl that part their ways. 
The narrator of this dominant metafictional work calls for the attention of reader through the fragmented ideology. Hamid narrates that pretty girl does not interfere in the life of rural boy by thinking that he would be happy with his wife but later on, he falsifies his imagination by the interference of pretty girl in his life. The falsification of ideas suggest that it is just illusion of the writer. Hamid points the character "you" and reader tries to alien himself with this imagination.

The aspirations and motivations of both "rural boy" and "pretty girl" are fragmented due to difference in their societies. Initially rural boy is presented as more attached with his family but as he grows up, he feels the need of physical love. He exchanges love with money whereas pretty girl exchanges money with love. Hamid handled the phenomenon of "love and money" with the sensational lexical items such as inspire, motivate, uplifts and kills. Every human being is motivated when confronted with opposite gender and extravagant money, but finally the abundance of longing for love and money diminish our youth and beauty and makes us fragile and eventually kills.

\section{Conclusion}

In this study, we have explored the struggle of Mohsin Hamid to legitimize the unheard voice of lay man in Asia, where he used multiple little narratives to highlight the fragmented society. He does not focus on the grand narratives, rather fragmented issues of contemporary Asians are connected together to get reader aware about the shaded reality or hyper-reality of society and to imagine themselves in that particular position. The entire novel highlights psychological, social, economic and cultural fragments (hybridity) that enhances the interest of reader. He has further enlarged the boundaries of traditional practicality and discussed the human capacity of survival in fragmented society. His jokes in novel are gloomy and mysterious, but are pervasive. He condemns the fragmented society that creates gap in lower middle class and elite class. He challenged the wisdom but he is skeptic about the truthfulness, politics, science and progress on the base of reason. Hamid has represented the fragmented society with reference to the text. In fragmented society, people earn money with bribery, corruption, nepotism and illicit dealings. Hamid left greater room for the reader to interpret the text by the use of linguistic fragmentation such as antithesis, anti-form plot with anaphoric and cataphoric references. 


\section{References}

Al-Nakeeb, O. A. M. S. (2018). Fragmentation of the fe/male characters in Final Flight from Sanaa: A corpus-based feminist stylistic analysis. International Journal of Applied Linguistics and English Literature, 7(3), 221-230.

Bendiksen, K. K. (2017). Postmodernist Fragmentation and Non-Linearity: An Experience of Time within the Capitalist Framework.

Best, S., \& Kellner, D. (1991). Postmodern Theory: Critical Interrogations. Guilford Press.

Davis, C. (2003). After Poststructuralism: Reading, Stories and Theory. Routledge.

Derrida, J. (1971). The deconstruction of actuality.

Duffy, M. F. (1989). Linguistic Fragmentation and Overseas Marketing Opportunities. Journal of International Consumer Marketing, 1(3), 27-43.

Federman, R. (1975). Surfiction : fiction now and tomorrow. 294.

Fowles, J. (1969). The French lieutenant's woman. 467.

Gass, W. H. (1998). Willie Masters’ Lonesome Wife. Dalkey Archive Press.

Gregson, I. (2004). Postmodern Literature. Arnold.

Hall, S. (1993). What is this" black" in black popular culture? Social Justice, 20(1/2 (51-52), 104114.

Hamid, M. (2013). How to get filthy rich in rising Asia. 228.

Hill, J., \& Pamela, C. G. (1998). The Oxford Guide to Film Studies. Oxford University Press.

Jackson, S., \& Jones, J. (1998). Contemporary Feminist Theories. Edinburgh University Press.

Jameson, F. (1991). Postmodernism, or, The cultural logic of late capitalism. 438.

Jones, R. W. (2000). A Framework for Fragmentation.

Littrup, L. (1996). Identity in Asian Literature. Curzon Press.

Lyotard, J.-F., Bennington, G., \& Massumi, B. (1984). The Postmodern Condition: A Report on Knowledge. In Poetics Today (Vol. 5). https://doi.org/10.2307/1772278

McRobbie, A. (1994). Postmodernism and popular culture. Psychology Press.

MOULAI, R. (2018). Fragmentation in Virginia Woolf's To the Lighthouse. Ministry of Higher Education.

NARGES, M. B. (2018). A Comparative Study of Postmodernism in Iranian and American Poetry (Vol. 10, pp. 241-261). Vol. 10, pp. 241-261. 
Norris, C. (1990). What's Wrong with Postmodernism: Critical Theory and the Ends of Philosophy.

Sim, S. (2011). The Routledge Companion to Postmodernism. Routledge.

Sontag, S. (1966). Against Interpretation, and Other Essays. Farrar Straus \& Giroux.

Wiley, N. (2012). The Post-modern Self: A Retrospective. Society, 49(4), 328-332.

Woolf, V. (1981). To the lighthouse. 209. 